\title{
Effect of Parity of Animal and Season of Year on the Rate of Retention of Placenta in Dairy Cattle
}

\author{
Mridula Sharma $^{{ }^{*}}$, Yaqoob Bhat ${ }^{1}$, Nishant Sharma ${ }^{2}$ and Shriya Rawat ${ }^{3}$ \\ ${ }^{1}$ Department of Veterinary Gynaecology and Obstetrics, College of Veterinary and \\ Animal Sciences, G. B Pant University of Agriculture and Technology, \\ Pantnagar-263145, Uttarakhand, India \\ ${ }^{2}$ Veterinary Officer at Animal Husbandry Department, Uttarakhand, India \\ ${ }^{3}$ SVPUA\&T, Meerut, India \\ *Corresponding author
}

\section{A B S T R A C T}

\section{Keywords}

Dairy cattle, Effect of season, Parity,

Retention of placenta, etc.

Article Info

Accepted:

23 October 2017

Available Online:

10 December 2017
A survey was conducted at IDF Nagla, Pantnagar, Uttrakhand from year 2003 to 2013 to observe the effect of season of year and parity of animal on the rate of retention of placenta in dairy cattle. All cases of retained placenta in dairy cattle were recorded and the analysis of data was conducted to assess the effect of season of year and parity of animal on the rate of retention of placenta. Cases of retention of placenta in primiparous animals were 88 and 251 in pleuriparous animals. The highest percentages of incidence of retained placenta was detected in spring and summer seasons $(29.20 \%$ and $27.72 \%$ respectively, while the lowest percentage was noticed in autumn (20.94\%). Rate of occurrence of retention of placenta is more common in pleuriparous animals than in the primiparous animals (heifers). The incidence of cases of retention of placenta was maximum in spring and summer season and minimum in autumn.

\section{Introduction}

Fetal membranes "placenta" is a vital organ for prenatal transfer of nutrients, oxygen and immunity from the mother to the fetus. It is normally expelled out with in short time post parturition. If the placenta is not expelled out within certain duration (12 hours post calving and 3 hours post foaling) (Mohamed et al., 2009 and Taylor et al., 2010), it is then defined as retention of placenta (ROP). This creates a number of problems such as, fever, weight loss, decreased milk yield, longer calving intervals and may result in an open cow during next year and if the infection is severe the animal may sometimes die. A retained placenta usually causes the cow to delay the next pregnancy for 2-6 months (Borel et al., 2006). ROP causes high economic losses which are mainly due to infertility caused by uterine infections. It also leads to decreased milk yield and calf crop. The actual causes of ROP are not clear, but this condition usually occurs after dystocia, mal and unbalanced nutrition, stress, hereditary predispositions or infections. Since 
there are many causes of ROP, there is no simple method for control and prevention. Basically we have to prevent the incidences of dystocia through good genetic selection of dam and sire having least probability for ROP, proper and good pre-partum nutrition schedule and exercise. Special care should be paid for nutrition and vitamin supplementation, especially during the dry period. Maintain a sound vaccination programme to minimize the chances of viral and bacterial abortions. Regular examination of the animal should be done for early diagnosis of dystocia. It could be concluded that ROP is an important problem which causes great economic losses and leave the animal sub-fertile even after treatment. So it is recommended to control the condition rather than to treat it.

The incidence of ROP varies from $4-16.1 \%$ in cow and it can be much higher in problem herds. It increases during summer with increased parity and following birth of male fetus (El-Malky et al., 2010; Ahmed et al., 1999).

Also there observed no significant differences in retained placenta percentage between winter and summer feeding as well as between male or female birthing (Gaafar, 2010). Information regarding effect of season on rate of placenta would be helpful to reduce the cases of retention of placenta in herd. Thus the present study is planned to see the effect of season and parity of animal on incidence of ROP.

\section{Materials and Methods}

The present study was based on data collection; the data during 2003-2013 was taken from record book maintained at the office of the Instructional Dairy Farm Nagla, GBPUAT, Pantnagar. Data was analyzed and simple statistics was applied to derive the results.

\section{Results and Discussion}

Effect of parity of animal and season of year on the rate of retention of placenta in dairy cattle is depicted in Figure 2 and 3. In year 2003, the total cases of retention of placenta recorded at IDF Nagla were 40. 5\% primiparous cows (02 in number) and 95\% pleuriparous cows (38 in numbers) were recorded to be suffering from retention of placenta. $27.5 \%$ cases occurred in spring, $32.5 \%$ in summer, $7.5 \%$ in autumn and $32.5 \%$ in winter.

In year 2004 the total cases of retention of placenta recorded at IDF Nagla were $40.22 \%$ primiparous cows (09 in number) and $77.5 \%$ pleuriparous cows (31 in numbers) were recorded to be suffering from retention of placenta. $32.5 \%$ cases occurred in spring, $25 \%$ in summer, $25 \%$ in autumn and $17.5 \%$ in winter.

In year 2005 the total cases of retention of placenta recorded at IDF Nagla were 29. $55.17 \%$ primiparous cows (16 in number) and $44.82 \%$ pleuriparous cows (13 in numbers) were recorded to be suffering from retention of placenta. $3.44 \%$ cases occurred in spring, $24.13 \%$ in summer, $37.83 \%$ in autumn and $34.48 \%$ in winter.

In year 2006 the total cases of retention of placenta recorded at IDF Nagla were 31. $25.80 \%$ primiparous cows ( 08 in number) and $74.19 \%$ pleuriparous cows (23 in numbers) were recorded to be suffering from retention of placenta. $45.16 \%$ cases occurred in spring, $29.03 \%$ in summer, $19.35 \%$ in autumn and $06.45 \%$ in winter.

In year 2007 the total cases of retention of placenta recorded at IDF Nagla were 44. $34.09 \%$ primiparous cows ( 15 in number) and $65.90 \%$ pleuriparous cows (29 in numbers) were recorded to be suffering from retention 
of placenta. $36.36 \%$ cases occurred in spring, $27.27 \%$ in summer, $20.45 \%$ in autumn and $15.90 \%$ in winter.

In year 2008 the total cases of retention of placenta recorded at IDF Nagla were 22. $13.63 \%$ primiparous cows (03 in number) and $86.36 \%$ pleuriparous cows (19 in numbers) were recorded to be suffering from retention of placenta. $40.9 \%$ cases occurred in spring, $18.18 \%$ in summer, $27.27 \%$ in autumn and $13.63 \%$ in winter.

In year 2009 the total cases of retention of placenta recorded at IDF Nagla were 37.
$37.83 \%$ primiparous cows (14 in number) and $62.16 \%$ pleuriparous cows (23 in numbers) were recorded to be suffering from retention of placenta. $18.91 \%$ cases occurred in spring, $29.72 \%$ in summer, $32.43 \%$ in autumn and $18.91 \%$ in winter.

In year 2010 the total cases of retention of placenta recorded at IDF Nagla were 31. $16.12 \%$ primiparous cows ( 05 in number) and $83.87 \%$ pleuriparous cows (26 in numbers) were recorded to be suffering from retention of placenta. $25.80 \%$ cases occurred in spring, $41.93 \%$ in summer, $16.12 \%$ in autumn and $16.12 \%$ in winter.

Fig.1 Retention of placenta cases in different years in dairy cattle
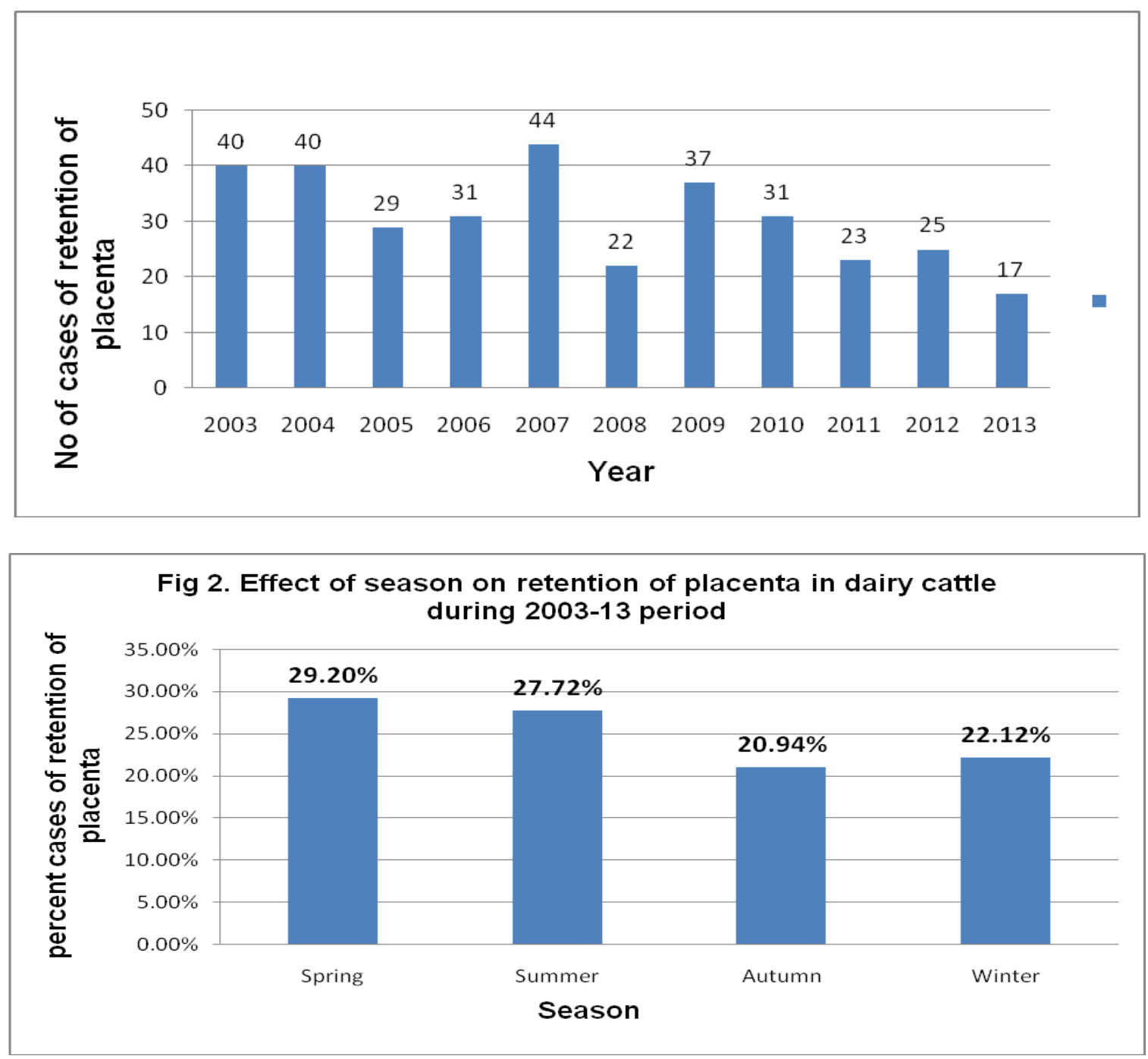


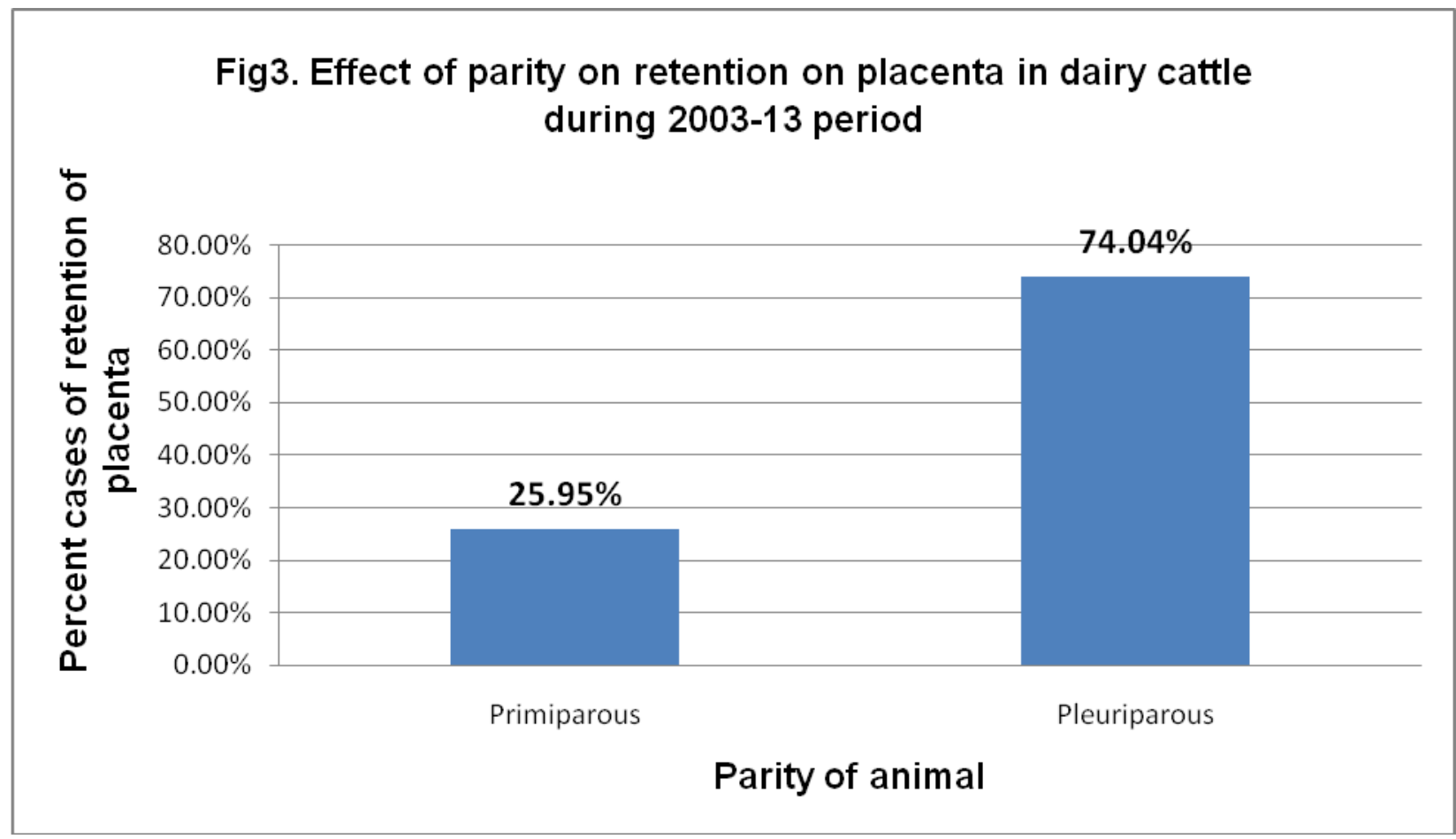

In year 2011 the total cases of retention of placenta recorded at IDF Nagla were 23. $34.78 \%$ primiparous cows (08 in number) and $65.21 \%$ pleuriparous cows (15 in numbers) were recorded to be suffering from retention of placenta. $17.39 \%$ cases occurred in spring, $30.43 \%$ in summer, $08.69 \%$ in autumn and $43.47 \%$ in winter.

In year 2012 the total cases of retention of placenta recorded at IDF Nagla were 25. $16.00 \%$ primiparous cows (04 in number) and $84.00 \%$ pleuriparous cows (21 in numbers) were recorded to be suffering from retention of placenta. 36\% cases occurred in spring, $12 \%$ in summer, $12 \%$ in autumn and $40 \%$ in winter.

In year 2013 the total cases of retention of placenta recorded at IDF Nagla were 17. $23.52 \%$ primiparous cows (04 in number) and $76.47 \%$ pleuriparous cows (13 in numbers) were recorded to be suffering from retention of placenta. $41.17 \%$ cases occurred in spring, $29.41 \%$ in summer, $23.52 \%$ in autumn and $05.88 \%$ in winter.
From the period of 2003 to 2013, the total cases of retention of placenta were 339 (Fig. 1). $25.95 \%$ cases occurred in primiparous cows (heifers) and $74.04 \%$ in pleuriparous cows. $29.20 \%$ (99 in numbers) cases occurred in spring, $27.72 \%$ (94 in numbers) cases occurred in summer, $20.94 \%$ (71 in numbers) in autumn and $22.12 \%$ (75 in numbers) cases in winter.

The highest percentages of incidence of retained placenta were detected in spring and summer seasons $(29.20 \%$ and $27.72 \%$ respectively), while the lowest percentage was noticed in autumn (20.94\%). Similar results were obtained by Gaafar (2010), Atalah (1993), Deyab (2000) and Gabr et al., (2005). The incidence of retention of placenta increases significantly with increasing body weight of cows, parity and body weight of calves born. There were no significant differences in the percentage of retained placenta between winter and summer feeding as well as between male or female birthing Gaafar (2010). Calvings during the summer or during periods of heat stress have been 
associated with higher incidences of retained placenta. There is decreased incidence of retained placenta in autumn (Chassagne et al., 2005).

The causes of the lower incidence in the fall season compared to hot season are due to the environmental and nutritional differences, e.g. temperature and concentrate to forage ration in the diet (Echternkamp and Gregory, 1999). Such seasonal differences in nutrition may influence placental development; placental growth (i.e., mass and net cellular proliferation) in the first half of gestation period (Ehrhardt and Ball, 1995). Calf birth weight and placental weight have been reported to be correlated positively in cattle (Echternkamp, 1993).

Above results reveal that the effect of parity on the incidence of retained placenta in dairy cows increases significantly from 1st parity onwards. It could be explained on the basis of the uterine muscles. These results are in accordance with those obtained by Karen (1996), Deyab (2000) and Gabr et al., (2005). They reported that the incidence of retained placenta increased in old cows with parity over fourth. Most of researcher showed similar results.

Sarder et al., (2010) showed the incidence of retained placenta at 1 st parity, 2nd parity, $3 \mathrm{rd}$ parity, 4th parity, 5th parity and $>6$ th parity ware $8.5 \%, 13.3 \%, 6.1 \%, 9.4 \%, 20 \%$ and $28.7 \%$, respectively which is closer to our study. Gaafar et al., (2010) reported the incidence of retained placenta in Friesian cows increased significantly from $14.20 \%$ for 1st parity to $54.60 \%$ for 8th parity. Azad, (2010) reported the rates of retention of placenta in $1^{\text {st }}, 2^{\text {nd }}, 3$ rd and 5 th parity were $15.0 \%, 15 \%, 33.3 \%$ and $37.5 \%$ respectively. Stevenson and Call, (1988) reported that retained placenta increases with advancing parity except in heifer.

\section{Conclusion}

By analyzing the above data, it was found that the rate of occurrence of retention of placenta is more common in pleuriparous animals than in the primiparous animals (heifers). The incidence of cases of retention of placenta is maximum in spring and summer season and minimum in autumn.

\section{Acknowledgement}

We are highly thankful and obliged for assistance and support provided by Dean, College of Veterinary sciences, GBPUAT, Pantnagr and Director Instructional Dairy Farm Nagla for the expertise that greatly assisted the present survey. We wish to express my gratitude to Mr. Sharma ji who is in charge of the record keeping unit at IDF Nagla for his cooperation in providing data for this study.

\section{Conflict of interest}

There is no conflict of interest. The results are in accordance with the opinion of authors.

\section{Authors' contribution}

All authors contributed technically in carrying out this research and finalizing this article

\section{References}

Ahmed, W.M., K.I. El-Ekhnawy, H.M. Dessouky, M.M. Zabal and Y.F. Ahmed, 1999. Invistigations on Retained Fetal membranes in Friesian cows in Egypt. Egypt. J. Comp. Pathol. Clin. Pathol, 12: 160-177.

Atalah, S. A. 1993. Some studies on reproductive disorders during pregnancy and prepartum in buffaloes. Ph. D. Thesis. 1993, Suez Canal Univ. 
Azad MA (2010). Prevention of retained placenta by injecting various drugs immediately after parturition in cows. MS Thesis, Department of Surgery and Obstetrics, Faculty of Veterinary Science, Bangladesh Agricultural University, Mymensingh. pp.1-48.

Borel, N., R. Thoma, P. Spaeni, R. Weilenmann, K. Teankum and E. Brugnera, 2006. Chlamydia-related abortions in cattle from Graubunden, Switzerland. Vet Pathol, 43: 702-8.

Chassagne M, Barnouin J, Faye B. Descriptive epidemiology of placental retention in intensive dairy herds in Brittany. Vet Res 1996, 27, 491-501

Deyab, H. H. S. 2000. Factors affecting placenta retention in cattle. Ph. D. Fac. of Agric., 2000, Minufiya Univ.

El-Malky, O., M. Youssef, N. Abdel-Aziz and A. Abd El-Salaam, 2010. Postpartum Performance Of Buffaloes Treated With Gnrh To Overcome The Impact Of Placenta Retention. J. American Sci., 2: 225-233.

Echternkamp, S. E. 1993. Relationships between placental development and calf birth weight in beef cattle. Animal Reproduction Science, 1993, vol. 32, p. $1-13$

Ehrhardt, R. A. - BELL, A. W. 1995. Growth and metabolism of the ovine placenta during mid-gestation. Placenta, 1995, vol. 16 , no. 8 , p. $727-741$
Gaafar H.M.A, Shamiah ShMA, Shitta A and Ganah HAB (2010). Factors affecting retention of placenta and its influence on postpartum reproductive performance and milk production in Friesian cows. Slovak Journal of animal science 4(1): $6-12$.

Gabr, Sh. A. - SHAMIAH, Sh. M. - ABU EL-HAMD, M. A. 2005. Factors related to the incidence of retained placenta in Friesian cows kept under Egyptian conditions. Journal of Agriculture Science Mansoura University, 2005, vol. 30, p. 6532.

Morel, M., 2005. Breeding horses. Blackwell, Oxford, UK., pp: 324-339.

Mohamed, A. and A. Amer, 2009. Hormonal and biochemical anomalies in dairy cows affected by retained fetal membranes. http://priory.com/vet/ cow_fetal_membrane.htm

Sarder MJU, Moni MIZ and Aktar S (2010). Prevalence of reproductive disorders of crossbred cows in the Rajshahi district of Bangladesh. SAARC Journal of Agriculture 8(2): 65-75.

Stevenson JS and Call EP (1988). Reproductive disorders in the parturient dairy cow. Journal of Dairy Science 71: 2572-2583.

Taylor, F., T. Brazil and M. Hillyer, 2010. Diagnostic Techniques in Equine Medicine. Second Edition, Saunders Elsevier.

\section{How to cite this article:}

Mridula Sharma, Yaqoob Bhat, Nishant Sharma and Shriya Rawat. 2017. Effect of Parity of Animal and Season of Year on the Rate of Retention of Placenta in Dairy Cattle. Int.J.Curr.Microbiol.App.Sci. 6(12): 3103-3108. doi: https://doi.org/10.20546/ijcmas.2017.612.362 